\title{
THE EFFECTIVENESS OF PEER REVIEW TO TEACH WRITING VIEWED FROM STUDENTS' MOTIVATION AT NINTH GRADE OF SMP N 1 SEKAMPUNG ACADEMIC YEAR 2014/2015
}

\author{
Leny Setiyana \\ Institut Agama Islam Negeri (IAIN), Metro \\ Email: lenysetiyana@gmail.com
}

\begin{abstract}
This research is aimed to examine whether ;(1) Peer Review is more effective than Think Pair Share Technique to teach writing for the ninth grade students; (2) The students with high motivation have better writing skill than those having low motivation for the ninth grade students; and (3) There is an interaction between teaching techniques and students' motivation in teaching writing for the ninth grade students. The method that was used in this research is experimental study. The samples were two classes namely experimental class which was taught using Peer Review and control class which was taught using Think Pair Share. Each class was divided into two groups of which each consisted of students having high motivation and those having low motivation. Two instruments were used to collect the data. The instruments were writing test and motivation's questionnaire. The data were analyzed by using Multifactor Analysis of Variance ANOVA 2x2 and Tukey Test. Before conducting ANOVA test, pre-requisite test was conducted. Based on the data analysis, the findings of this research are; (1) Peer Review technique is more effective than Think Pair Share technique to teach writing; (2) The students with high motivation have more better writing skill than those having low motivation; and (3) There is an interaction between teaching techniques and students's motivation in teaching writing. The research result of this study implies that Peer Review technique is effective to teach writing for the ninth grade students.
\end{abstract}

Keywords : Peer Review Technique, Think Pair Share Technique, Writing Skill, Motivation, Experimental Study

\section{INTRODUCTION}

English becomes one of the parts in compulsory subjects which exist in some levels of education. Education system of Indonesia has made English as the one of subjects in education program. Learners or students of school or university should be able to master some basics English skills in the form of listening, speaking, reading and writing. Besides the skills, learners should be able to comprehend three elements of English that are phonology, vocabulary and grammar. All of the skills and elements above, writing become one of the English skills that should be mastered by learners.

Writing is one of the important skills in English. Jahin (2012: 60) states that writing has become a subject in today's schools and 
universities as a measure for academic success. Most of people think that speaking has a big role in communication. In reality, writing also gives role in the way of communication. It involves the development of an idea and the experience of subject. Demirel (2011: 222):

" that writing is seen as important for the development of the thinking and organizational skills of second language writers, as well as helping them to test hypotheses about the new language by providing a time to process meaning in a less stressful way compared to oral production."

Brown (2001: 336) states that writing is a thinking process, a writer produces a final written product based on their thinking after the writer goes through the thinking process. Writing also plays important role in the success of learning. In addition, the writing skill is complex and sometimes difficult to teach, requiring mastery not only of grammatical and rhetorical devices but also of conceptual and judgmental element (Heaton, 1975: 135). Considering the difficulties of writing as the thinking process, writing skill becomes the skill which need higher thinking in such of aspect includes concept, grammatical, rhetorical devices, and so forth.

Writing as one of the four skills in English is considered as the most difficult and most challenging skill for foreign learners compared to the other skills either for most students or even for teachers. According to Sharples (1999: 8) actually, writing is an opportunity; it allows students to express something about themselves, explore and explain ideas. Siburian (2013: 30) explains that student can convey their ideas in their mind by organizing them into a good text so that the others know them and they can think critically. In reality, there are many cases in which students have difficulties in producing good compositions. The difficulties of learners in writing are lack of skill to write. This is a common difficulties that faced by learners. Another factor is writing experience. Learners who have little experience in writing will stuck in conveying their idea.

It is very important to develop learners' skill in writing. One of the ways to develop learners' writing skill is by using teaching technique. Setiyadi (2006:14) states that technique is something that actually takes place in language teaching or learning in the classroom. Teachers are expected to apply a teaching technique which can motivate learners and encourage students to involve in the classroom activity.

There are many techniques which were developed by experts in teaching learning process. In this research, the researcher only focuses on two teaching techniques. Those techniques are Peer Review and Think Pair Share Technique.

Peer Review is one of techniques which are used in teaching writing. Peer Review is a process where students read drafts written by their fellow students and give each other suggestion to improve the writing (Lee, 1997:58). The focus of Peer Review is on the review process which includes not 
only editing, evaluating, and assessing, but also responding to the content of the essay and how the essay is written (Mangelsdorf,1992:274-284). Peer Review makes students do more with their friend draft. Besides giving evaluation, students also need to know how to develop writing or an essay in order to give a good respond.

The implementation of Peer Review is considered as the complete and useful technique in teaching writing skill. Jahin (2012: 60) states that many studies have indicated the positive effect of Peer Review on the writing process and on the writer's product. Peer Review makes students more active than before. Lee (1997: 58) peer review is a process where students read drafts written by their fellow students and give each other suggestions to improve the writing. By using this technique, students will develop their thinking process and their ability to give judgment or feedback to their friends' writing.

Think Pair Share is a collaborative teaching technique that encourages individual participation and is applicable across all grade levels and class sizes. According to Lyman (1992: 109) TPS is cooperative learning technique, involving individual pairs and group of students. Khotiyal et al (2013: 1) describe that Think-Pair-Share (TPS) is a classroom-based active learning strategy, in which students work on a problem posed by the instructor, first individually, then in pairs, and finally as a class wide discussion. The think pair share proposes an active learning in which the students do the classroom activity with their friend. Think Pair Share has three activities. The activities involve three basic steps. During the 'think' stage, the teacher tells students to ponder a question or problem. The 'pair' stage, the students are paired up and discuss their answer or solution to the problem. The last stage 'share', students are called to share with the rest of class.

Motivation plays an important role in teaching and learning process. Gardner (1985:23) defines motivation as referring to a combination of effort plus desire to achieve the goal of learning the language plus favorable attitude towards learning the language. Ryan and Deci (2000: 60) define motivation as concerning energy, direction, and persistence-all aspects of activation and intention. Students who know how to do are usually work harder than who do not know. Motivation deals with why individual get interested to events that get their attention. According to Brown (2000: 168), there are three different perspectives emerge in motivation; they are from behavioral perspective, a cognitive view, and a constructivist view.

The research aims:

1. To know whether Peer Review is more effective than Think Pair Share technique to teach writing skill to students of SMP N 1 Sekampung in the academic year of 2014/2015.

2. To know whether the students who have high learning motivation have better writing skill than those who have low learning motivation. 
3. To know whether there is an interaction between teaching techniques and learning motivation to teach writing skill to students of SMP N 1 Sekampung in the academic year of 2014/2015.

The hypothesis of this research are :

1. Peer Review is more effective than Think Pair Share in teaching writing to the students of SMP N 1 Sekampung in the academic year of 2014/2015.

2. Students with high motivation have better writing skill than those with low motivation of the students of SMP N 1 Sekampung in the academic year of 2014/2015.

3. There is an interaction between teaching techniques and the students' motivation in teaching writing to the students of SMP N 1 Sekampung in the academic year of 2014/2015.

\section{RESEARCH METHODOLOGY}

The research was conducted at SMP $\mathrm{N} 1$ Sekampung. It was located at Jl. 56 A Bangkok, Sekampung Kab. Lampung Timur, Lampung. The method of this research was experimental research. The design of the research was $2 \times 2$ factorial design. The two classes divided into two, experimental class and control class. The experimental class was taught by using Peer Review technique, while the control class was taught by using Think Pair Share. Both of classes received a test from attributive variable that is motivation. The motivation divided into two levels; high and low level.

Based on the title and background of the research, the population was the ninth graders student of SMP N 1 Sekampung in the academic year of 2014/2015. There are five classes of ninth grade. The classes were IX.1, IX.2, IX.3, IX.4, and IX.5. Each class consists of 40 students. The total number of students was 200 students.

The samples of the research were taken from classes of ninth graders at the odd semester students of SMP N 1 Sekampung. The samples were two classes. The first class was IX.1 as experimental group and the second was IX.2 as control group.

In determining the sample, the researcher employed cluster random sampling technique to the total population.. Two classes were taken as the samples and in determining which two classes out of four were chosen as the samples, the researcher chose the class randomly. Then, the researcher decided which one of the two classes were the experimental group and the control group.

In the process of conducting the test, the students were assigned to write descriptive text. The test was conducted after the students were given the treatments or taught by using peer review for experimental group and think pair share for control group. In this research, the researcher used writing test. It is graded by using scoring rubric which was included content, grammatical rules, organization, vocabulary, and mechanics. 
Based on the research design, the researcher gave a sheet of questionnaire dealing with students' motivation. The type of the questionnaire used closed questionnaire since this type is easier to be applied. Before being applied, the questionnaire was tried out to analyze its validity and reliability.

In analyzing the data, there were several techniques of analyses to be done. There techniques were: (1) data description by using inferential analysis. It was used to know the distribution, in the form of table and histogram, mean, mode, median, and standard deviation; (2) pre-requisite tests which included normality test and homogeneity test; and (3) hypothesis tests which included Analysis of Variance (ANOVA) and Tukey Test.

\begin{tabular}{lccccc} 
RESULT AND DISCUSSION & \\
$\begin{array}{c}\text { The Result of ANOVA } \\
\text { The }\end{array}$ & & \\
\hline $\begin{array}{c}\text { Source of } \\
\text { Variance }\end{array}$ & $\mathrm{SS}$ & $\mathrm{df}$ & $\mathrm{MS}$ & $\mathrm{F}_{\mathrm{o}}$ & $\mathrm{F}_{\mathrm{t}}$ \\
\hline $\begin{array}{c}\text { between } \\
\text { coloumns } \\
\text { between } \\
\text { rows }\end{array}$ & 1901.25 & 1 & 1901.25 & 41.93 & 4.49 \\
$\begin{array}{c}\text { coloumns by } \\
\text { rows }\end{array}$ & 211.25 & 1 & 211.25 & 4.66 & \\
$\begin{array}{c}\text { between } \\
\text { group }\end{array}$ & 2535.70 & 3 & 845.23 & & \\
within & 3446.10 & 76 & 45.34 & & \\
group & & & & & \\
Total & 5981.80 & 79 & & & \\
\hline
\end{tabular}

Peer review is more effective than Think Pair Share to teach writing

The result of the study shows that there is a significant difference between teaching writing using Peer
Review and teaching writing using Think Pair Share. Generally the result is, Peer Review is more effective than Think Pair Share to teach writing. Lee (1997: 58) peer review is a useful technique for encouraging revision in writing than think pair share. This technique is more effective than other techniques like Think Pair Share which proposes three stages of writing. Peer review provides a true incentive for students to revise their work. Peer Review is the technique of teaching which can guide students to write or compose the writing.

Levine et al (2002) state that this activity offers an opportunity for the students to discuss and develop ideas about the content of their writing as well as to help each other in improving their writing skills that Peer Review makes the students more focus on correcting the other writing. Students learn to become more autonomous writers as they are prepared to write without the help of a teacher (Jacobs, 1989). Through collaborative learning, students can gain a better understanding of their peers' difficulties in writing, and as a result they may gain more confidence in themselves (Mittan,1989).

Lee (1997: 58) peer review is a process where students read drafts written by their fellow students and give each other suggestions to improve the writing. Giving suggestion to other writings can help students to improve their writing ability. This activity trains all students to be a good corrector and motivate them to give a good correction to their fellow. Peer reviews also provide opportunities 
for collaborative learning. Students inpairs or small groups can pool ideas, and it is through interacting with others that students learn and develop (Vygotsky, 1978)

The focus of Peer Review is on the review process which includes not only editing, evaluating, and assessing, but also responding to the content of the essay and how the essay is written (Mangelsdorf,1992:274-284). In peer review technique, teacher provided a checklist paper to help students to correct other works. This guidance has some points which help them to correct the writing. Most of students sometimes they do not know how to check and give suggestion or correction to their friends' writing. By using Peer Review technique, the students are trained how to be a good reviewer so that they be able to give right suggestion and correction.

In think pair share technique, students make their writing together with their peer. Although the students made the writing with their peer, some of lacks occurred in this activity. This activity can make students lazier to write because they will let their friends to do it by themselves. Although think pair share proposes students to do the task in group but the real condition is only one of them that work by themselves.

Based on the explanation above, we can conclude that peer review is more effective than think pair share in teaching writing. In doing peer review, the teacher gives the students a checklist which helps them to correct their fellow writing.

\section{The students having high motivation have better writing ability than those having low motivation}

Motivation is one of factors which influence the successful of learning of the students. Everyone has different level of motivation which affects them to do something and pushes them to get something. Harmer (2001: 51) states that motivation is kind of internal drive which pushes someone to do things in order to achieve something. It means that motivation has an important role to people or in this condition are the students to encourage them and push them to write or compose the writing based on their ideas. Based on the research, high motivated students is better in learning than low motivated students. Writing is a skill which asks students to develop and to express the idea. This activity needs a high motivation from students itself to do it. The students with high motivation are able to write well. Winkel (1996: 150) states that learning motivation plays an important role to promote the spirit of learning so that students with high motivation have strong energy to perform learning. Mittan (207-219: 1989) indicates that peer reviews enhance students' motivation and confidence to write and improve their writing skills. The students with high motivation will force themselves hardly to achieve a good score by doing a good composition of writing. It can be proved by the activity that they have done in the writing class. High motivated students try to keep their 
concentration and direction to achieve their goal.

According to Weiner in Elliot (2000: 332) states that motivation is an internal state that arouses us to action, pushes us in particular direction, and keep us engaged in certain activities. It assumes that motivation has a great role in determining the success of the learning process to reach the goal of learning and the students' activeness. It means that the students with low motivation probably will face difficulties in learning process while students with high motivation can reach the learning goal easily. Students with high motivation tend to participate actively in learning process. They often ask questions and like to share idea with their friends.

There are some characteristics of students who have high motivation: (1) They have greater effort in pursuing success; (2) they have strong intention to learn more than what is given in the class; (3) they tend to be active in learning activities and problem solving, and this makes them experience many things; (4) they are eager to find other learning resources to make their work better; (5) they are curious to know more than what they get from the teacher.

The students with low motivation tend to ignore the learning activity or do not have courage to be active students. The students do not motivate to express their idea or thought. They think that writing is difficult and useless to them. These kinds of reason become the common reasons for low motivated students to write in
English. Based on the explanation above, it can be concluded that the student who have high motivation are better writing ability than the students who have low motivation.

\section{Interaction between teaching techniques and motivation}

The right teaching technique will encourage learners in developing their idea in writing. Finding a good technique in teaching learning process, especially for teaching writing skill is very difficult. A good technique will influence learners in learning. Peer Review is an effective technique for students in writing class. A study done by Mittan (207219: 1989) indicates that peer reviews enhance students' motivation and confidence to write and improve their writing skills.

In Peer Review technique, students collaborate to the other students or their classmate to assess and give suggestions to other writing in order to make a good composition in writing. This activity encourages the high motivated students to give right correction to their teammate. Students are helped to correct the writing by using a guiding checklist paper. This paper is given by teacher to students which show each part of writing aspects that should be corrected. By applying peer review to teach writing, teacher is trying to increase the students' motivation and confidence to evaluate their friends writing.

Mittan (1989: 207) describes that there are some positive impacts of peer reviewing, such as enhancing positive attitude towards writing within ESL/EFL learners; giving students a sense of audience; 
increasing their motivation and confidence in their writing; helping them learn to evaluate their own writing better. Based on the explanation above it can be concluded that Peer Review is suitable for high motivated students.

On the other side, students who have low motivation do not have courage to do something, in this case is writing. Low motivated students tend to ignore the activity that happened in the classroom. Think Pair Share is a technique consists of three steps. Each step should be executed by students. Low motivated students will be bored because there are many steps in doing the technique. In conclusion, Think Pair Share is suitable for low motivated students.

\section{CONCLUSION}

Based on the result of the hypotheses testing, the research findings are as follows: (1) The students who are taught using Peer Review have better writing skill than who are taught using Think Pair Share. Thus, the use of Peer review is more effective than Think Pair Share to teach writing to the ninth graders of SMP N 1 Sekampung; (2) The students who have high motivation have better writing skill than those who have low motivation of ninth graders at SMP $\mathrm{N} 1$ Sekampung academic year 2014/2015; (3) There is an interaction between teaching techniques and motivation to teach writing to the ninth grade students of SMP N 1 Sekampung in the academic year 2014/2015.

\section{REFERENCES}

Brophy, J. 1998. Motivating Students to Learn. New York: McGraw-Hill

Brophy, J. 2004. Motivating Students to Learn. New Jersey: Lawrence Erlbaum Associates

Brown, H.D. 2001. Teaching by Principles An Interactive Approach to Language Pedagogy $\quad 2^{\text {nd }}$ edition.Longman

Brown, H. Douglas. 2004. Language Assessment: Principles and Classroom Practice. New York: Longman

Brown, S \& Hood, K. 1989. Writing Matters: writing Skills and Strategies for students of English. Cambridge University Press:New York

Deci, E. L., \& Ryan, R. M. 1995. Human Autonomy: The Basis for True Self-Esteem. In M. H. Kernis (Ed.), Efficacy, Agency and SelfEsteem (pp. 31-49). New York: Plenum

Demirel, E. 2011. Take it Step by Step: Following a Process Approach to Academic Writing to Overcome Student Anxiety. Journal of Academic Writing, Vol. 1 No 1, 222-227

Gardner, R. C. 1985a. Social psychology and second language learning: The role 
of attitudes and motivation. London: Edward Arnold Publishers.

Goddard, W \& Melville, S. 2006. Research Methodology: An Introduction $2^{\text {nd }}$ Edition. Juta: Lansdowne

Harlen W and Deakin Crick R . 2002. A systematic review of the impact of summative assessment and tests on students' motivation for learning. In: Research Evidence in Education Library. London: EPPICentre, Social Science Research Unit, Institute of Education, University of London.

Harmer, Jeremy. 2001. How to Teach English: An Introduction to the practice of English Language Teaching. Longman: London

Harmer, Jeremy. 2001. How to Teach English: An Introduction to the practice of English Language Teaching $3^{\text {rd }}$ Edition. Longman: London

Jahin,J.H. 2012. The Effect of Peer Reviewing on Writing Apprehension and Essay Writing Ability of Prospective EFL Teachers. Australian Journal of Teacher Education, vol.37 (11) p60-84

Khanalizadeh, Bita \& Allami, Hamid. 2012. The Impact of Teachers' Belief on EFL
Writing Instruction. Theory and Practice in Language Studies, Vol. 2, No. 2, pp. 334-342, February 2012 ACADEMY PUBLISHER Manufactured in Finland. doi:10.4304/tpls.2.2.334342

Kothiyal, A.,Majunrndar, R.,Murthy, S \& Iyer, S. 2013. Effect of Think Pair Share in a Large CSI Class: $83 \%$ Sustained Engagement. ICER'13, August 12-14, 2013, San Diego, California, USA.

Lee, I. 1997. Peer Review in Hong Kong Tertiory Classroom. Tesl Canada journal/la revue TESL du Canada Vol.15,no.1, p58-69

Lyman, F. 1987. Think-Pair-Share: An expanding teaching technique: $\quad M A A-C I E$ Cooperative News, v. 1, pp 1-2.

Mangelsdorf, K.(1992).Peer Review in the ESL classroom: What do the students think? ELTJ, 46,274-284.

Mittan, R. 1989. The Peer Review Process: Harnessing Students' communicative Power. In D.M. Johnson \& D.H. Roen (Eds). Richness in Writing: Empowering ESL Students (pp.207219). White Plains, NY: Longman

Ryan, R. M., Kuhl, J., \& Deci, E. L. 1997. Nature and 
Autonomy: Organizational View of Social and Neurobiological Aspects of Self-Regulation in Behavior and Development. In Ryan, R. M., \& Deci, E. (2000). Self-Determination Theory and the Facilitation of Intrinsic Motivation, Social Development, and Well Being. American Psychologist, 78, 199-221.

Setiyadi, B.2006. Teaching English As a Foreign Language.Yogyakarta:

Graha Ilmu

Siburian, A.T. 2013. Improving Students' Achievement on Writing Descriptive Text Through Think Pair Share. International Journal of Language Learning and Applied Linguistics World (IJLLALW)

Volume3(3),July2013; 3043 EISSN:2289-2737 \& ISSN:2289-324 